UDK 577.1 : 61

ISSN 1452-8258

\title{
SPECIFIC IMPACT OF CARDIOVASCULAR RISK FACTORS ON CORONARY MICROCIRCULATION IN PATIENTS WITH SUBCLINICAL HYPOTHYROIDISM
}

\author{
SPECIFIČAN UTICAJ KARDIOVASKULARNIH FAKTORA RIZIKA NA KORONARNU \\ MIKROCIRKULACIJU U PACIJENATA SA SUBKLINIČKOM HIPOTIREOZOM
}

\author{
Mirjana Stojkovic 1,2, Biljana Nedeljkovic-Beleslin 1,2, Milorad Tesic 1,3, Zoran Bukumiric 1,4, \\ Jasmina Ciric 1,2, Milos Stojanovic 1,2, Marija Miletic 1,2, Ana Djordjevic-Dikic 1,3, Vojislav Giga 1,3, \\ Branko Beleslin 1,3, Milos Zarkovic ${ }^{1,2}$ \\ ${ }^{1}$ Faculty of Medicine, University of Belgrade, Belgrade, Serbia \\ ${ }^{2}$ Clinic of Endocrinology, Diabetes and Metabolic Disease, University Clinical Centre of Serbia, Belgrade, Serbia \\ ${ }^{3}$ Clinic for Cardiology, University Clinical Centre of Serbia, Belgrade, Serbia \\ ${ }^{4}$ Instuitute of Medical Statistics and Informatics, Faculty of Medicine, University of Belgrade, Belgrade, Serbia
}

\begin{abstract}
Summary
Background: Although thyroid hormones have significant effect on cardiovascular system, the impact of subtle thyroid dysfunction such as subclinical hypothyroidism $(\mathrm{SCH})$ remains to be determined. We investigated coronary flow reserve (CFR) in patients with subclinical hypothyroidism. Methods: Thirty two subjects with $\mathrm{SCH}$ and eighteen control subjects with normal serum thyroid hormones and thyroid-stimulating hormone (TSH) levels were included in the study. TSH, free thyroxine, free triiodothyronine, glucose, insulin, HbA1c, cholesterol, triglyceride and plasma levels of C-reactive protein were measured. Coronary diastolic peak flow velocities in left anterior descending coronary artery were measured at baseline and after adenosine infusion. CFR was calculated as the ratio of hyperemic to baseline diastolic peak velocity.

Results: CFR values were not significantly different between the two groups ( $\mathrm{SCH} 2.76 \pm 0.35$ vs controls $2.76 \pm 0.42$ ). There was a significant correlation of CFR with waist to hip ratio, hypertension, smoking habits, markers of glucose status (glucose level, HbA1c, insulin level, HOMA IR), cholesterol, LDL-cholesterol and triglyceride levels in $\mathrm{SCH}$ group, whereas only cholesterol level showed significant correlation with CFR in controls. There was no correlation between CFR and thyroid hormones.
\end{abstract}

\section{Kratak sadržaj}

Uvod: Poznato je da tiroidni hormoni imaju značajan efekat na kardiovaskularni sistem, ali i dalje ostaje da se utvrdi uticaj suptilnih promena na nivou tiroidne osovine kao što je subklinička hipotireoza (SHT). Ispitivali smo koronarnu rezervu protoka (KRP) kod pacijenata sa subkliničkim hipotireoidizmom.

Metode: Trideset dva ispitanika sa subkliničkom hipotireozom i osamnaest kontrolnih ispitanika sa urednim tiroidnim hormonskim statusom su bili uključeni u studiju. Mereni su TSH, fT4, fT3, glukoza, insulin, HbA1c, holesterol, trigliceridi i CRP. Koronarne dijastolne brzine protoka u levoj prednjoj silaznoj koronarnoj arteriji merene su na početku i nakon infuzije adenozina. Koronarna rezerva protoka je izračunata kao odnos hiperemijske i osnovne dijastolne brzine protoka.

Rezultati: Vrednosti koronarne rezerve protoka se nisu značajno razlikovale između dve grupe (SHT 2,76 \pm 0,35 $\mathrm{u}$ odnosu na kontrole 2,76 $\pm 0,42$ ). Postojala je značajna korelacija KRP sa odnosom struka i kukova, hipertenzijom, navikama pušenja, markerima glikoregulacije (nivo glukoze, HbA1c, nivo insulina, HOMA IR), holesterolom, LDLholesterolom i nivoom triglicerida u SHT grupi, dok je samo nivo holesterola pokazao značajnu korelaciju sa KRP u kontrolnoj grupi. Nije bilo korelacije između KRP i hormona štitaste žlezde.

\footnotetext{
Address for correspondence:

Mirjana Stojković

Clinic of Endocrinology, Diabetes and Metabolic Disease,

University Clinical Centre of Serbia, Dr Subotica 13,

11000 Belgrade, Serbia

phone: +381-69-3755-440

fax: +381-11-2685-357

e-mail: mirjana.stojkovic@gmail.com
}

List of abbreviations: $\mathrm{SCH}$, subclinical hypothyroidism; CFR, coronary flow reserve; $L A D$, left anterior descending coronary artery; DPFV, diastolic peak flow velocity 
Conclusions: We concluded that there is a different impact of cardiovascular risk factors on CFR in $\mathrm{SCH}$ patients compared to healthy control and that these two groups behave differently in the same circumstances under the same risk factors. The basis for this difference could be that the altered thyroid axis "set point " changes the sensitivity of the microvasculature in patients with $\mathrm{SCH}$ to known risk factors.

Keywords: cardiovascular risk factors, coronary flow reserve, subclinical hypothyroidism, thyroid

\section{Introduction}

Subclinical hypothyroidism ( $\mathrm{SCH}$ ) is defined as mild elevation of thyroid-stimulating hormone (TSH) in the presence of normal free thyroxine (fT4) and free triiodothyronine (fT3) levels (1). It is well known that overt hypothyroidism has negative impact on cardiovascular function $(2,3)$. The clinical importance of subclinical hypothyroidism in cardiovascular disease and mortality is still controversial, because of the inconsistent results (4-6), on the impact of $\mathrm{SCH}$ on cardiovascular function. Several studies including meta-analyses have suggested that there is an association between $\mathrm{SCH}$ and cardiovascular diseases $(2,3$, 7-10), and that $\mathrm{SCH}$ is an independent risk factor for atherosclerosis and myocardial infarction in elderly women (11). Razvi et al. (12) in their meta-analysis postulated that $\mathrm{SCH}$ is associated with increased cardiovascular morbidity and mortality only in younger subjects. On the other hand, in the last few years there were several studies that did not show relation between $\mathrm{SCH}$ and cardiovascular disease or cardiovascular and all-cause mortality $(5,13,14)$. Likewise, treatment of subclinical hypothyroidism in older persons did not show any clinical benefit (15).

Coronary flow velocity reserve (CFR) is defined as the ratio of hyperemic coronary blood flow velocity to baseline and reflects functional integrity of coronary microcirculation. It has been shown that reduced CFR is an early manifestation of atherosclerosis and coronary artery disease (16). CFR measured by transthoracic Doppler echocardiography (TTDE) has an excellent correlation with CFR measured by positron emission tomography, which has been validated as a gold standard for noninvasive CFR measurement (17).

The present study was designed to investigate the impact on persistent $\mathrm{SCH}$ on the value of CFR, as assessed by transthoracic Doppler echocardiography, and consequently microcirculatory function.

\section{Materials and Methods}

The study group consisted of 32 patients with newly diagnosed persistent $\mathrm{SCH}$ (31 female, one male; mean age $52.6 \pm 14.8$ years), and 18 healthy controls (17 female, one male; mean age 50.1 15.4
Zaključak: Zaključili smo da postoji drugačiji uticaj kardiovaskularnih faktora rizika na koronarnu rezervu protoka kod pacijenata sa subkliničkom hipotireozom u poređenju sa zdravom kontrolom i da se ove dve grupe ponašaju različito $\mathrm{u}$ istim okolnostima, pod istim faktorima rizika. Osnova za ovu razliku mogla bi biti da promenjen "set point « tiroidne osovine menja osetljivost mikrovaskulature kod pacijenata sa SHT na poznate faktore rizika.

Ključne reči: kardiovaskularni faktori rizika, koronarna rezerva protoka, subklinička hipotireoza, štitasta žlezda

years). $\mathrm{SCH}$ was diagnosed on the basis of persistent TSH increase with free thyroid hormones level within the referent range. Patients were included in the study only if they had stable $\mathrm{SCH}$ which was demonstrated by repeated thyroid hormone profile after minimum four weeks. The institutional ethics committee approved the study protocol, and all participants signed informed consent to the study.

The exclusion criteria for $\mathrm{SCH}$ group as well as for the control group were history of coronary artery disease, valvular or congenital heart disease, cardiac rhythm abnormalities, diabetes mellitus, systemic, hepatic or renal diseases. Controls had a normal thyroid hormonal status.

All blood samples were collected between 08.00 and $09.00 \mathrm{~h}$ in the morning after overnight fast. Serum lipid levels (total cholesterol, high-density lipoprotein cholesterol, triglyceride), $\mathrm{HbA} 1 \mathrm{c}$ and fasting glucose levels were measured using spectrophotometry commercial kits on an automatic analyzer c501 (Roche Diagnostics, GmbH, Mannheim, Germany). C-reactive protein values were analyzed by Immunoturbidimetric assay for the in vitro quantitative determination on a Cobas c501 analyzer (Roche Diagnostics, GmbH, Mannheim, Germany), using the latex-enhanced immunoturbidimetric assay. Low density lipoprotein cholesterol was calculated by Friedewald's formula. The serum TSH, fT4, fT3, TPOAb and insulin levels were measured using a electrochemiluminescence immunoassay (ECLIA) on the Roche Cobas e601 automated analyzer (Roche Diagnostics, Mannheim, Germany) and using a chemiluminescent microparticle immunoassay (CMIA) on an Alinity instrument (Abbott Diagnostics, Wiesbaden, Germany). Normal range for TSH was 0.27-4.2 $\mathrm{mlU} / \mathrm{L}$, for $\mathrm{fT} 3$ was $3.1-6.8 \mathrm{pmol} / \mathrm{L}$, for fT4 12-22 pmol/L and for TPOAb 0-34 $\mathrm{IU} / \mathrm{mL})$. Body mass index (BMI), waist-to-hip ratio (WHR) and HOMA IR were also calculated, using standard formulas. Systolic and diastolic blood pressures (BP) were measured on the right arm of subjects in an upright sitting position after at least $5 \mathrm{~min}$ of rest using a sphygmomanometer.

CFR was performed using the Acuson Sequoia C 256 (Siemens Medical Solutions, Mountain View, CA, USA) with 4-MHz transducer. With the patient 
positioned in the left lateral decubitus, coronary flow was searched for in the mid/distal portion of the left anterior descending (LAD) coronary artery with the transducer placed at the cardiac apex or one intercostal space higher in order to obtain modified, threechamber view. Color Doppler imaging was performed by decreasing the Nyquist limit to $1624 \mathrm{~cm} / \mathrm{s}$. With a sample volume $3-5 \mathrm{~mm}$ wide and positioned on the LAD color flow signal in diastole, pulsed Doppler tracings of peak flow velocities were recorded. After acquiring Doppler tracings in baseline conditions, under continuous echocardiographic monitoring, adenosine $140 \mathrm{mg} / \mathrm{kg} / \mathrm{min}$ was administrated over 2 min and peak diastolic coronary flow velocities were obtained during maximal hyperemia. Three optimal flow profiles at rest and during hyperemia were obtained and results were averaged. CFR was calculated as the ratio of hyperemic to baseline diastolic flow velocities. Preserved CFR was defined as 2.0. All patients abstained from caffeine-containing drinks for at least 12 hours before the tests.

\section{Statistical analysis}

Results were presented as mean \pm standard deviation, frequency (percent) and median (range) in case of not normal distribution of data. Chi-square test was used to test differences between nominal data (frequencies). For parametric data independent samples t-test was used to test differences between groups. For numeric data with non-normal distribution and ordinal data Mann-Whitney $U$ test was used. Chi-square test or Fisher's exact test were used to test differences between nominal data (frequencies). Correlation between the CFR for LAD as dependent variable and potential predictors was analyzed by linear regression. All p-values less than 0.05 were considered significant.

\section{Results}

Age, gender, BMI, glucose, insulin levels, $\mathrm{HOMA}$ IR, cholesterol, HDL, LDL, levels, systolic and diastolic blood pressure, smoking habits were similar in $\mathrm{SCH}$ group and in controls. Triglyceride levels were higher in $\mathrm{SCH}$ group, whereas CRP also showed borderline higher values in $\mathrm{SCH}$ group. The fT3/fT4 ratio was

Table I Patients characteristic.

\begin{tabular}{|c|c|c|c|}
\hline & $\begin{array}{c}\mathrm{SCH} \text { group } \\
(\mathrm{n}=32)\end{array}$ & Control group $(n=18)$ & $P$ \\
\hline Age & $52.6 \pm 14.8$ & $50.1 \pm 15,4$ & 0.509 \\
\hline Male/female & $1 / 31$ & $1 / 17$ & 0.595 \\
\hline $\mathrm{BMI}$ & $26.6 \pm 5.1$ & $24.2 \pm 3.0$ & 0.069 \\
\hline WHR & $0.84 \pm 0.07$ & $0.82 \pm 0,06$ & 0.620 \\
\hline Hypertension (\%) & $40.6 \%$ & $38.9 \%$ & 0.904 \\
\hline Systolic BP (mmHg) & $120.3 \pm 11.6$ & $119.4 \pm 10.1$ & 0.792 \\
\hline Diastolic BP $(\mathrm{mmHg})$ & $75.8 \pm 7.8$ & $73.3 \pm 7.3$ & 0.283 \\
\hline Smokers (\%) & $21.9 \%$ & $22.2 \%$ & 0.923 \\
\hline Glycose $(\mathrm{mmol} / \mathrm{L})$ & $5.5 \pm 0.7$ & $5.4 \pm 0.6$ & 0.708 \\
\hline Insulin (mIU/L) & $8.5(1.4-23.5)$ & $6.8(1.4-16.1)$ & 0.983 \\
\hline HbA1c (\%) & $5.7 \pm 0.4$ & $5.5 \pm 0.3$ & 0.212 \\
\hline HOMA IR & $1.8(0.3-6.7)$ & $1.6(0.3-3.6)$ & 0.861 \\
\hline Cholesterol $(\mathrm{mmol} / \mathrm{L})$ & $5.60 \pm 1.02$ & $5.63 \pm 1.08$ & 0.914 \\
\hline $\mathrm{HDL}(\mathrm{mmol} / \mathrm{L})$ & $1.48 \pm 0.32$ & $1.67 \pm 0.53$ & 0.113 \\
\hline $\mathrm{LDL}(\mathrm{mmol} / \mathrm{L})$ & $3.47 \pm 0.85$ & $3.46 \pm 0.70$ & 0.986 \\
\hline Triglyceride $(\mathrm{mmol} / \mathrm{L})$ & $1.30(0.48-3.66)$ & $0.97(0.52-2.19)$ & 0.044 \\
\hline CRP (nmol/L) & $1.3(0.3-9.6)$ & $0.7(0.1-2.1)$ & 0.051 \\
\hline fT4 (mgl/L) & $11.8 \pm 1.6$ & $12.6 \pm 1.7$ & 0.082 \\
\hline fT3 (pmol/L) & $4.03 \pm 0.42$ & $4.01 \pm 0.42$ & 0.881 \\
\hline fT3/fT4 & $0.35 \pm 0.05$ & $0.31 \pm 0.04$ & 0.015 \\
\hline $\mathrm{TSH}(\mathrm{mlU} / \mathrm{L})$ & $7.70(4.60-15.35)$ & $2.08(0.51-4.14)$ & $<0.001$ \\
\hline TPOAb (IU/mL) & 248.5 (4-7413.5) & 14.4(0.3-793.3) & $<0.001$ \\
\hline
\end{tabular}

$\mathrm{BMI}$ - body mass index; WHR - waist to hip ratio 
Table II Coronary flow velocity values in $\mathrm{SCH}$ and controls.

\begin{tabular}{|l|c|c|c|}
\hline & $\begin{array}{c}\text { SCH group } \\
(\mathrm{n}=32)\end{array}$ & $\begin{array}{c}\text { Control group } \\
(\mathrm{n}=18)\end{array}$ & $\mathrm{P}$ \\
\hline $\begin{array}{l}\text { Baseline DPVF } \\
\text { of LAD }(\mathrm{cm} / \mathrm{s})\end{array}$ & $0.27 \pm 0.04$ & $0.26 \pm 0.06$ & 0.402 \\
\hline $\begin{array}{l}\text { Hyperemic } \\
\text { DPVF of LAD } \\
(\mathrm{cm} / \mathrm{s})\end{array}$ & $0.75 \pm 0.18$ & $0.70 \pm 0.17$ & 0.379 \\
\hline CFR & $2.76 \pm 0.35$ & $2.76 \pm 0.42$ & 0.999 \\
\hline
\end{tabular}

DPVF - diastolic peak flow velocity; CFR - coronary flow reserve; $\mathrm{LAD}$ - left arterior descending coronary artery

Table III Univariate linear regression with CFR for LAD as dependent variable.

\begin{tabular}{|c|c|c|c|c|}
\hline \multirow{2}{*}{ Variable } & \multicolumn{2}{|c|}{ SCH group } & \multicolumn{2}{c|}{ Control group } \\
\cline { 2 - 5 } & $\mathrm{B}$ & $\mathrm{p}$ & $\mathrm{B}$ & $\mathrm{p}$ \\
\hline Age & -0.012 & 0.003 & -0.019 & 0.002 \\
\hline BMI & -0.013 & 0.282 & -0.018 & 0.610 \\
\hline WHR & -2.090 & 0.013 & -1.897 & 0.307 \\
\hline Hypertension & 0.249 & 0.045 & 0.362 & 0.075 \\
\hline $\begin{array}{c}\text { Systolic } \\
\text { tension }\end{array}$ & -0.010 & 0.066 & -0.013 & 0.192 \\
\hline $\begin{array}{c}\text { Dyastolic } \\
\text { tension }\end{array}$ & -0.010 & 0.231 & -0.013 & 0.362 \\
\hline Smokers & -0.256 & 0.037 & 0.033 & 0.877 \\
\hline Glucose & -0.249 & 0.006 & -0.311 & 0.063 \\
\hline HbA1c & -0.357 & 0.021 & -0.547 & 0.168 \\
\hline Insulin & -0.023 & 0.024 & -0.013 & 0.629 \\
\hline HOMA. IR & -0.102 & 0.009 & -0.116 & 0.326 \\
\hline Cholesterol & -0.165 & 0.005 & -0.179 & 0.056 \\
\hline HDL & -0.077 & 0.701 & -0.334 & 0.082 \\
\hline LDL & -0.160 & 0.028 & -0.166 & 0.153 \\
\hline Triglyceride & -0.195 & 0.020 & 0.146 & 0.496 \\
\hline CRP & -0.008 & 0.798 & -0.043 & 0.815 \\
\hline fT4 & 0.038 & 0.337 & -0.016 & 0.810 \\
\hline fT3 & 0.057 & 0.693 & 0.340 & 0.216 \\
\hline fT3/fT4 & -0.790 & 0.496 & 4.873 & 0.150 \\
\hline TSH & 0.009 & 0.698 & 0.121 & 0.169 \\
\hline TPOAb & $<0.001$ & 0.802 & 0.001 & 0.124 \\
\hline & & & & \\
\hline
\end{tabular}

significantly higher in $\mathrm{SCH}$ group, as well as titer of thyroid peroxidase (TPOAb) autoantibodies (Table I).

Baseline diastolic peak flow velocity (DPFV) of LAD was similar between the groups, as well as hyperemic DPFV. Accordingly, there was no statistically significant difference in CFR for LAD between the $\mathrm{SCH}$ group and the control group, and all the values in both groups were above the preserved limit of
CFR (2.0), but with a wide range of scatterplot data (Table II).

By univariate linear regression analysis with CFR for LAD as dependent variable, CFR was inversely associated with the age and total cholesterol values in controls, whereas in $\mathrm{SCH}, \mathrm{CFR}$ was related to the age, hypertension, smoking, total and LDL cholesterol, triglycerides, and glucose metabolism deterioration, and waist-hip ratio, implicating specific contributory effect of cardiovascular risk factors on CFR in patients with $\mathrm{SCH}$ (Table III). There was no association between TSH level and CFR nor between fT4 level and CFR in both control and $\mathrm{SCH}$ group.

\section{Discussion}

We have shown that in patients with $\mathrm{SCH}$, microcirculatory function as assessed by 2D Doppler echocardiography derived CRF is generally preserved with wide scatter of data and without significant differences to patients with normal thyroid function. However, it seems that in patients with $\mathrm{SCH}$, in comparison to normal thyroid function, the value of CFR is more dependent on traditional cardiovascular risk factors including hypertension, smoking, high cholesterol, and glucose metabolism deterioration. CFR by Doppler echocardiography, over last 10 years has been shown to be highly reproducible, efficacious and feasible noninvasive to assess microcirculatory dysfunction in different clinical scenarios affecting coronary microcirculation $(18,19)$.

Based on a large number of studies and meta analyses conducted in the last twenty years, it is clear that $\mathrm{SCH}$ leads to a somewhat increased risk for cardiovascular disease, cardiovascular mortality and overall mortality $(2,3,6,9,11,12,20,21)$, but the pathophysiologic mechanisms involved in this phenomenon are still to be defined.

Since subclinical hypothyroidism is a laboratory finding, the diagnosis of $\mathrm{SCH}$ should be made with caution. Different physiological conditions as well as other diseases can change the pituitary-thyroid axis, i.e. lead to a transient increase in TSH. There is also an increase in TSH with age, and this increase does not lead to increased cardiovascular mortality CVD (22). One way to overcome such doubts is to prove persistently elevated TSH over a period of time, and as Hashimoto's thyroiditis is the most common cause of both overt and subclinical hypothyroidism (1), finding of elevated TPOAb could reinforce the diagnosis of $\mathrm{SCH}$ (23). In our study the $\mathrm{SCH}$ group showed a significantly higher titer of TPOAb compared to the control group, thus confirming the existence of an autoimmune process in the thyroid gland in $\mathrm{SCH}$ group. We also confirmed persistently higher TSH values which, after initial elevated values, were confirmed by TSH re-determination. There was a significant increase in the fT3/fT4 ratio in the $\mathrm{SCH}$ group 
in our study, which we know to represent the adaptive mechanism of the thyroid axis due to increased activity of deiodinase 2 (D2), which mediates T4 to T3 conversion, as well as due to higher $\mathrm{TSH}$-induced increase of T3 synthesis and secretion from the thyroid gland (24).

Of all anthropometric and biochemical parameters, only C-reactive protein (CRP) and triglyceride level were significantly higher in the $\mathrm{SCH}$ group than in the controls. This agrees with studies that have shown similar results $(25,26)$. CRP is known to be a strong independent risk factor for cardiovascular events (27), not only among those with stable and unstable angina (28) but also among individuals with no current evidence of cardiovascular disease (29). Triglyceride level was also higher in $\mathrm{SCH}$ group in two large observational studies $(30,31)$, and it is well known that elevated plasma triglyceride level is an independent risk factor for cardiovascular disease (32). The values of cholesterol, its fractions and glycose related parameters (basal glucose level, insulin, HOMA IR) did not differ significantly between groups, which was also shown in some of the published papers $(30,33)$, but there are also papers that show a significant difference between groups in relation to these parameters $(34,35)$.

Only four studies have previously evaluated CFR in middle-aged patients with $\mathrm{SCH}$ (36-39). The two of them used dipyridamole (36) and adenosine (37) as a stressor, and both adenosine and dipyridamole induce a hyperaemic stimulus that relaxes vascular smooth muscle cells in mostly endothel-independent way. In the third study, conducted by the Oflaz et al. (38) CFR for LAD was evaluated before and after the introduction of levothyroxine replacement therapy. The fourth study evaluated endothelial-mediated $\mathrm{CRF}$ in $\mathrm{SCH}$ subjects using cold pressor test to induce endothelium-dependent vasodilation (39). Importantly, in comparison to previous studies our study did not find significant deterioration of CFR in $\mathrm{SCH}$ patients $(36,37,39)$.

In particular, Baycan et al. (36) in $50 \mathrm{SCH}$ patients and 30 controls (hyperaemia was induced by dipyridamole), showed no significant difference in anthropometric and biochemical parameters between the groups (BMI, lipids, CRP), but a significant deterioration of CFR due to blunted hyperaemic response in $\mathrm{SCH}$ group (2.38 \pm 0.44 vs. $2.98 \pm 0.47$, $\mathrm{p}<0.0001$ ) (36).

Oflaz et al. (37) with a smaller group of subjects (18 SCH, 24 controls) and adenosine as a stimulus of hyperaemia-endothelium independent vasodilation obtained similar results for CFR (SCH $1.97 \pm 0.09$ vs. controls $2.58 \pm 0.08$. The same authors evaluated CFR for LAD before and after the introduction of levothyroxine replacement therapy and showed that there was a significant increase in CFR for LAD in $\mathrm{SCH}$ group after six month levothyroxine substitution
$(2.03 \pm 0.13$ vs $2.54 \pm 0.18)$ but the study was conducted on only ten patients with $\mathrm{SCH}$ (38).

Biondi et al. (39) also showed a significant difference in CFR between the $\mathrm{SCH}$ and control group (SCH 20, control 15), but they induced endotheliumdependent vasodilation and hyperaemia using a cold pressor test as an inducer ( $\mathrm{SCH} 1.4 \pm 0.2$ vs. controls $1.9 \pm 0.3 p<0.0001$ ) (39).

It is challenging to explain about the significant differences between our and previous results in CFR values, but few points should be emphasized regarding our study population, methodology and results. Our study population was older (SCH $52.6 \pm 14$, 8; controls $50.1 \pm 15,4)$ than study populations in Oflaz et al. (37) (SCH $45 \pm 2$; controls $48 \pm 2$ years), Baycan et al. (36) (41.4 \pm 9.5; controls $41.3 \pm 9.4$ years) and Biondi et al. (39) (SCH38.4 \pm 12.1; controls $41.4 \pm 14.5$ years), and since CRF is significantly negatively correlated with age, it is possible that the subtle vascular changes that might be detected in $\mathrm{SCH}$ are outweighed by changes due to aging. Further, in the study by Biondi et al. (39) CFR was measured after induction of endothelium-dependent vasodilatation, while in the remaining tree studies, including our study, endothelium-independent vasodilatation was induced. And third, all of these studies were performed on a relatively small number of subjects.

If we look at the dependence of CFR for LAD in our study, it is expected that in both groups there is a significant dependence of CFR on the age of the subjects. However, apart from age, there is only a significant dependence of CFR for LAD on total cholesterol in the control group. It is interesting, however, that in the $\mathrm{SCH}$ group, the dependence of CFR for LAD on several anthropometric and metabolic parameters (WHR, HTA, smoking, glycemia, HbA1c, basal insulin, HOMA IR, cholesterol, LDL, triglycerides) was obtained. These results suggest that individuals with subclinical hypothyroidism are more sensitive to certain metabolic, proatherogenic parameters, and this finding could be one of the explanations for the increased morbidity and mortality from cardiovascular disease in patients with $\mathrm{SCH}$, which has been shown in several studies and meta-analyzes (2, 3, 9, 10). Since CRP is shown to be higher in patients with $\mathrm{SCH}$ compared to healthy controls, low but prolonged chronic inflammation could be the basis for greater sensitivity of the microvasculature in patients with $\mathrm{SCH}$ to other known cardiovascular risk factors and mechanism linking SCH and CVD, i.e. that SCH facilitate the effect of traditional risk factors on microvascular function.

\section{Study limitations}

Our study reflects a single-center experience with a relatively small number of participants. Second, 
the cross-sectional design of our study limits its ability to establish causality between $\mathrm{SCH}$ and $\mathrm{CFR}$, and long-term effects of $\mathrm{SCH}$ on microcirculatory and cardiovascular function.

\section{Conclusion}

Our study has shown that people with subclinical hypothyroidism have a higher risk of chronic inflammation, which plays an important role in the development of atherogenesis and thus an increased risk of developing CHD. We also showed that in patients with $\mathrm{SCH}$ several known risk factors for atherogenesis have a significant impact on CFR for LAD which is not the case in the control group. Although we did not find a significant difference between groups in relation to CFR for LAD, the differ-

\section{References}

1. Cooper DS. Subclinical Hypothyroidism. N Engl J Med 2001; 345(4): 260-5.

2. Rodondi N, Aujesky D, Vittinghoff E, Cornuz J, Bauer DC. Subclinical Hypothyroidism and the Risk of Coronary Heart Disease: A Meta-Analysis. Am J Med 2006; 119(7): 541-51.

3. Ochs N, Auer R, Bauer DC, Nanchen D, Gussekloo J, Cornuz J, et al. Meta-analysis: subclinical thyroid dysfunction and the risk for coronary heart disease and mortality. Ann Intern Med 2008; 148(11): 832-45.

4. Rodondi N, Newman AB, Vittinghoff E, de Rekeneire N, Satterfield S, Harris TB, et al. Subclinical hypothyroidism and the risk of heart failure, other cardiovascular events, and death. Arch Intern Med 2005; 165(21): 2460-6.

5. López Rubio MA, Tárraga López PJ, Rodríguez Montes JA, Frías López M del C, Solera Albero J, Bermejo López P. [Subclinical hypothyroidism and cardiovascular risk]. Nutr Hosp 2015; 31(5): 2095-102.

6. Walsh JP, Bremner AP, Bulsara MK, O'Leary P, Leedman $\mathrm{PJ}$, Feddema $\mathrm{P}$, et al. Subclinical thyroid dysfunction as a risk factor for cardiovascular disease. Arch Intern Med 2005; 165(21): 2467-72.

7. Bastenie PA, Vanhaelst L, Bonnyns M, Neve P, Staquet $M$. Preclinical hypothyroidism: a risk factor for coronary heart-disease. Lancet Lond Engl 1971; 1(7692): 2034.

8. Bastenie PA, Vanhaelst L, Golstein J, Smets P. Asymptomatic autoimmune thyroiditis and coronary heart-disease. Cross-sectional and prospective studies. Lancet Lond Engl 1977; 2(8030): 155-8.

9. Sun J, Yao L, Fang Y, Yang R, Chen Y, Yang K, et al. Relationship between Subclinical Thyroid Dysfunction and the Risk of Cardiovascular Outcomes: A Systematic Review and Meta-Analysis of Prospective Cohort Studies. Int J Endocrinol 2017; 2017: 8130796. ent impact of cardiovascular risk factors on CFR for LAD suggests that these two groups behave differently in the same circumstances under the same risk factors. The basis for this difference could be that the altered "set point" of the thyroid axis changes the sensitivity of the microvasculature in patients with $\mathrm{SCH}$ to known risk factors, making them more susceptible for low prolonged chronic inflammation. Further investigations on a larger number of participants are needed to address in depth the relation between $\mathrm{SCH}, \mathrm{CFR}$, chronic inflammation and cardiovascular risk factors.

\section{Conflict of interest statement}

All the authors declare that they have no conflict of interest in this work.

10. Moon S, Kim MJ, Yu JM, Yoo HJ, Park YJ. Subclinical Hypothyroidism and the Risk of Cardiovascular Disease and All-Cause Mortality: A Meta-Analysis of Prospective Cohort Studies. Thyroid Off J Am Thyroid Assoc 2018; 28(9): 1101-10.

11. Hak AE, Pols HA, Visser TJ, Drexhage HA, Hofman A, Witteman JC. Subclinical hypothyroidism is an independent risk factor for atherosclerosis and myocardial infarction in elderly women: the Rotterdam Study. Ann Intern Med 2000; 132(4): 270-8.

12. Razvi S, Shakoor A, Vanderpump M, Weaver JU, Pearce SHS. The Influence of Age on the Relationship between Subclinical Hypothyroidism and Ischemic Heart Disease: A Metaanalysis. J Clin Endocrinol Metab 2008; 93(8): 2998-3007.

13. Tohidi M, Derakhshan A, Akbarpour S, Amouzegar A, Mehran L, Baghbani-Oskouei A, et al. Thyroid Dysfunction States and Incident Cardiovascular Events: The Tehran Thyroid Study. Horm Metab Res Horm Stoffwechselforschung Horm Metab 2018; 50(1): 37-43.

14. de Jongh RT, Lips P, van Schoor NM, Rijs KJ, Deeg DJH, Comijs HC, et al. Endogenous subclinical thyroid disorders, physical and cognitive function, depression, and mortality in older individuals. Eur J Endocrinol 2011; 165(4): 545-54.

15. Stott DJ, Rodondi N, Kearney PM, Ford I, Westendorp RGJ, Mooijaart SP, et al. Thyroid Hormone Therapy for Older Adults with Subclinical Hypothyroidism. N Engl J Med 2017; 376(26): 2534-44.

16. Britten MB, Zeiher AM, Schächinger V. Microvascular dysfunction in angiographically normal or mildly diseased coronary arteries predicts adverse cardiovascular long-term outcome. Coron Artery Dis 2004; 15(5): 259-64.

17. Kataoka Y, Nakatani S, Tanaka N, Kanzaki H, Yasuda S, Morii I, et al. Role of Transthoracic Doppler-Determined 
Coronary Flow Reserve in Patients With Chest Pain. Circ J 2007; 71(6): 891-6.

18. Tesic M, Djordjevic-Dikic A, Beleslin B, Trifunovic D, Giga $\mathrm{V}$, Marinkovic J, et al. Regional difference of microcirculation in patients with asymmetric hypertrophic cardiomyopathy: transthoracic Doppler coronary flow velocity reserve analysis. J Am Soc Echocardiogr Off Publ Am Soc Echocardiogr 2013; 26(7): 775-82.

19. Djordjevic Dikic A, Tesic M, Boskovic N, Giga V, Stepanovic J, Petrovic $M$, et al. Prognostic Value of Preserved Coronary Flow Velocity Reserve by Noninvasive Transthoracic Doppler Echocardiography in Patients With Angiographically Intermediate Left Main Stenosis. J Am Soc Echocardiogr Off Publ Am Soc Echocardiogr 2019; 32(1): 74-80.

20. Inoue K, Ritz B, Brent GA, Ebrahimi R, Rhee CM, Leung AM. Association of Subclinical Hypothyroidism and Cardiovascular Disease With Mortality. JAMA Netw Open 2020; 3(2): e1920745-e1920745.

21. Cappola AR, Fried LP, Arnold AM, Danese MD, Kuller $\mathrm{LH}$, Burke GL, et al. Thyroid status, cardiovascular risk, and mortality in older adults. Jama 2006; 295(9): 103341.

22. Dağdeviren $M$, Akkan T, Yapar D, Karakaya S, Dağdeviren T, Ertuğrul D, Altay M. Can neutrophil/lymphocyte ratio be used as an indicator of inflammation in patients with hyperthyroidism? J Med Biochem 2020, 39 (1): 7-12.

23. Pearce EN, Farwell AP, Braverman LE. Thyroiditis. N Engl J Med 2003; 348(26): 2646-55.

24. Bianco AC, Salvatore D, Gereben B, Berry MJ, Larsen PR. Biochemistry, Cellular and Molecular Biology, and Physiological Roles of the lodothyronine Selenodeiodinases. Endocr Rev 2002; 23(1): 38-89.

25. Tuzcu A, Bahceci M, Gokalp D, Tuzun Y, Gunes K. Subclinical hypothyroidism may be associated with elevated high-sensitive c-reactive protein (low grade inflammation) and fasting hyperinsulinemia. Endocr J 2005; 52(1): 89-94.

26. Kvetny J, Heldgaard PE, Bladbjerg EM, Gram J. Subclinical hypothyroidism is associated with a low-grade inflammation, increased triglyceride levels and predicts cardiovascular disease in males below 50 years. Clin Endocrinol (Oxf) 2004; 61(2): 232-8.

27. Ridker PM, Cook N. Clinical usefulness of very high and very low levels of $\mathrm{C}$-reactive protein across the full range of Framingham Risk Scores. Circulation 2004; 109(16): 1955-9.

28. Haverkate F, Thompson SG, Pyke SD, Gallimore JR, Pepys MB. Production of C-reactive protein and risk of coronary events in stable and unstable angina. European Concerted Action on Thrombosis and Disabilities Angina Pectoris Study Group. Lancet Lond Engl 1997; 349(9050): 462-6.

29. Ridker PM, Cushman M, Stampfer MJ, Tracy RP, Hennekens $\mathrm{CH}$. Inflammation, aspirin, and the risk of cardiovascular disease in apparently healthy men. $\mathrm{N}$ Engl J Med 1997; 336(14): 973-9.

30. Hueston WJ, Pearson WS. Subclinical Hypothyroidism and the Risk of Hypercholesterolemia. Ann Fam Med 2004; 2(4): 351-5.

31. Lai $Y$, Wang J, Jiang F, Wang B, Chen Y, Li M, et al. The relationship between serum thyrotropin and components of metabolic syndrome. Endocr J 2011; 58(1): 23-30.

32. Austin MA, Hokanson JE, Edwards KL. Hypertriglyceridemia as a Cardiovascular Risk Factor. Am J Cardiol 1998; 81(4, Supplement 1): 7B-12B.

33. Vierhapper H, Nardi A, Grösser P, Raber W, Gessl A. Lowdensity lipoprotein cholesterol in subclinical hypothyroidism. Thyroid Off J Am Thyroid Assoc 2000; 10(11): 981-4.

34. Walsh JP, Bremner AP, Bulsara MK, O'leary P, Leedman PJ, Feddema $P$, et al. Thyroid dysfunction and serum lipids: a community-based study. Clin Endocrinol (Oxf) 2005; 63(6): 670-5.

35. Garduño-Garcia J de J, Alvirde-Garcia U, LópezCarrasco G, Padilla Mendoza ME, Mehta R, ArellanoCampos $\mathrm{O}$, et al. TSH and free thyroxine concentrations are associated with differing metabolic markers in euthyroid subjects. Eur J Endocrinol 2010; 163(2): 273-8.

36. Baycan S, Erdogan D, Caliskan M, Pamuk BO, Ciftci O, Gullu $\mathrm{H}$, et al. Coronary Flow Reserve Is Impaired in Subclinical Hypothyroidism. Clin Cardiol 2007; 30(11): 562-6.

37. Oflaz H, Kurt R, Cimen A, Elitok A, Onur I, Golcuk E, et al. Coronary flow reserve is also impaired in patients with subclinical hypothyroidism. Int J Cardiol 2007; 120(3): 414-6.

38. Oflaz H, Kurt R, Sen F, Onur I, Cimen AO, Elitok A, et al. Coronary flow reserve after I-thyroxine therapy in Hashimoto's thyroiditis patients with subclinical and overt hypothyroidism. Endocrine 2007; 32(3): 264-70.

39. Biondi $B$, Galderisi $M$, Pagano L, Sidiropulos $M$, Pulcrano $M, D^{\prime}$ Errico A, et al. Endothelial-mediated coronary flow reserve in patients with mild thyroid hormone deficiency. Eur J Endocrinol 2009; 161(2): 323-9. 